\title{
Selection of Trichogramma species for controlling the Diamondback moth
}

\author{
Dirceu Pratissoli; Ricardo A Polanczyk; Anderson M Holtz; Leandro P Dalvi'; Alexandre F Silva; \\ Luciano N Silva \\ UFES-CCA, Lab. Entomologia, C. Postal 16, 29500-000 Alegre-ES; leandropin@yahoo.com.br. 'Corresponding author
}

\begin{abstract}
Biological characteristics of the egg parasitoids Trichogramma acacioi, T. atopovirilia, and T. bennetti were studied to select the one with better performance on the control of the Diamondback moth, Plutella xylostella. Parasitism rate, viability, and sex ratio were studied. Parasitism rate ranged from 1.67 to $41.33 \%$. T. atopovirilia and $T$. acacioi were respectively the most and less aggressive species. The viability ranged from $6.20 \%$ for $T$. acacioi to $53.34 \%$ for $T$. atopovirilia. There were no differences on sex ratio $(\mathrm{p}<0.05)$ that remained above 0,88 . T. atopovirilia was the species with best performance in the laboratory when rearing on the Diamondback moth eggs.
\end{abstract}

Keywords: Plutella xylostella, biological control, egg parasitoids, parasitism, sex ratio, viability.

\begin{abstract}
RESUMO
Seleção de espécies de Trichogramma visando o controle da traça-das-crucíferas

Foram estudados os aspectos biológicos das espécies Trichogramma acacioi, T. atopovirilia e T. bennetti, com o objetivo de selecionar aquela com melhor desempenho, para utilização no controle da traça-das-crucíferas, Plutella xylostella. As características biológicas avaliadas foram parasitismo, viabilidade e razão sexual. A taxa de parasitismo variou entre 1,67 e 41,33\%, sendo o maior valor observado para o T. atopovirilia e, o menor, para $T$. acacioi. A viabilidade variou entre $6,20 \%$ para $T$. acacioi a $53,34 \%$ para T. atopovirilia. Não houve diferença significativa para a razão sexual, ( $\mathrm{p}<0,05)$, que ficou acima de 0,88. T. atopovirilia foi a espécie de melhor desempenho em laboratório quando criada sobre ovos da traça-das-crucíferas.
\end{abstract}

Palavras-chave: Plutella xylostella, controle biológico, parasitóide de ovos, parasitismo, agressividade, razão sexual.

(Recebido para publicação em 27 de novembro de 2007; aceito em 11 de abril de 2008)

$\mathrm{T}$ he Diamondback moth, Plutella xylostella (L.) (Lepidoptera: Plutellidae), is a cosmopolitan microlepdoptera. It is the most important pest for crucifer crops, particularly for cabbage. In a global range, the Diamondback moth causes production losses up to $60 \%$. For this reason, the use of control measures to keep the pest population below the damage level is unavoidable (Imenes $e t$ al., 2002).

The Diamondback moth control is complex due to the all year round presence on cabbage fields, which guarantees abundant and continuous forage to the pest. In addition, the feeding behavior inside the cabbage heads gives larvae an extra protection (Imenes et al., 2002). Traditionally, the Diamondback moth is controlled by chemical insecticides. Up to four weekly sprays are carried out in the fields, using different active principles, either as a single ingredient or in mixes, which favors the breeding of pest resistant populations (Villas Boas et al., 2004). The intensive use of chemicals can also result in a resurgence of the target-pest, as well as give rise to new pests. The bulk of these chemicals has a high level of both biological action and environmental persistence, with potential to cause harm to consumers and workers engaged in the production process (Pereira et al., 2004a).

The high socio-economic cost of traditional insecticides opens a door to the search for alternatives to pest control that combine efficiency and ecological compatibility. The use of biological agents is a relevant tool in the development of integrated pest management programs, which are an option to reduce the insecticide use in the Diamondback moth control. The insects of the Trichogramma genus are a promising alternative as biological agents. Trichogramma are microhymennoptera that parasitize eggs of countless agricultural and forestry pests, mainly Lepidoptera. These insects are under use in biological control programs of a number of crops, in inundative releases, in about 23 countries (Hassan et al., 1998). According to Haji et al.
(2002), the use of Trichogramma is experiencing a mounting growth in latest years. Their mass production is easy and cheap and, with large amounts of Trichogramma at hand, inundative releases can quickly suppress the pest in a step prior to crop damage. To achieve good results with natural enemies, it is important to know their biological characteristics when in interaction with the target host. The selection of the most adequate parasitoid species is vital for any program of biological control (Parra et al., 2002).

The objective of this work was to study the development of Trichogramma acacioi (Brun, Moraes \& Soares), $T$. atopovirilia (Oatmam \& Platiner), and T. bennetti (Nagaraja \& Nagarkatti) using the Diamondback moth as host, aiming at the identification of the most suitable species for use in programs of biological control of this pest.

\section{MATERIAL AND METHODS}

The experiment was carried out at the Entomology Sector, at the Nucleus 
Table 1. Parasitism rate, viability, and sexual ratio of Trichogramma atopovirilia, T. bennetti, and T. acacioi reared in Plutella xylostella eggs (taxa de parasitismo, viabilidade e razão sexual de T. atopovirilia, T. bennetti, e T. acacioi criados em ovos de Plutella xylostella). Alegre, UFES, 2006.

\begin{tabular}{|c|c|c|c|}
\hline Species & Parasitism Rate ${ }^{1}(\%)$ & Viabilility $^{1}$ & Sexual Ratio $^{1}$ \\
\hline T. atopovirilia ${ }^{2}$ & $41,33 \pm 3,12 a$ & $53,34 \pm 1,02 \mathrm{a}$ & $0,88 \pm 0,06 a$ \\
\hline T. bennetti ${ }^{2}$ & $12,00 \pm 2,08 b$ & $43,40 \pm 2,72 b$ & $0,97 \pm 0,08 a$ \\
\hline T. acacioi $^{2}$ & $1,67 \pm 1,26 \mathrm{c}$ & $6,20 \pm 1,35 \mathrm{c}$ & $0,99 \pm 0,01 a$ \\
\hline
\end{tabular}

Means followed by the same letter in the column did not differ from each other, Tukey test, $\mathrm{p}<0.05$ (médias seguidas de mesma letra na coluna não diferem entre si, teste de Tukey, $\mathrm{p}<0,05$ ); ${ }^{1}$ Means are followed by the standard means error (as médias são seguidas pelo erro-padrão da média); ${ }^{2}$ Lab conditions to rear the Trichogramma were $25 \pm 1{ }^{\circ} \mathrm{C}, \mathrm{RH}=$ $70 \pm 10 \%$, and 14-h photoperiod (as condições de laboratório para a criação do Trichogramma foram $25 \pm 1{ }^{\circ} \mathrm{C}, \mathrm{UR}=70 \pm 10 \%$ e fotoperíodo de $14 \mathrm{~h}$ )

for Scientific and Technological Development on Phytosanitary Management (NUDEMAFI), located at the Center for Agricultural Sciences of UFES (CCA-UFES), in Alegre, Espirito Santo State, Brazil. During the experiment, the temperature was kept at $25 \pm 1^{\circ} \mathrm{C}$ and, the relative humidity, at $70 \pm 10 \%$. A 14 -hour photoperiod was used.

The Diamondback moth eggs were obtained from mass-rearing, according to the methodology adopted by Barros \& Vendramin (1999). The rearing and multiplication of the Trichogramma species were based on the methodology described by Parra (1997), adapted to the conditions of the Entomology Sector at the NUDEMAFI. The species $T$. acacioi, $T$. atopovirilia, and T. bennetti were evaluated, using 75 near-borne females, 25 from each species. Individual females were placed in glass tubes $(8.5 \times 2.4 \mathrm{~cm})$, closed with PVC film. In each tube, we introduced a azure cardboard $(3,5 \times 0,5 \mathrm{~cm})$ containing 30 P. xylostella eggs, with less than 12 hours of age. Eggs were collected from collard leaf disks using a moistened thin hairy brush, and then glued in the cardboards with Arabic gum at 10\%. At the end of 24 hours, females were removed from the tubes, which were kept in an acclimatized chamber $\left(25 \pm 1^{\circ} \mathrm{C}, 70 \pm 10 \% \mathrm{RH}\right.$, and 14-hour photoperiod) until adults' emergence.

For all the species studied, parasitism rate, viability, and sexual ratio were assessed. The experiment was carried out in a completely randomized design. Data were submitted to the analysis of variance and means were compared by the Tukey test, $\mathrm{p}<0.05$.

\section{RESULTS AND DISCUSSION}

There were significant differences among the three Trichogramma species when reared on the Diamondback moth. The parasitism rate varied from 1.67 , for T. acacioi, to $41.33 \%$, for T. atopovirilia (Table 1). Differences in the parasitism rate occur due to the direct dependence of parasitism potential on the parasitoid species and/or strain, host, and environmental conditions (Hassan, 1997). Bleicher \& Parra (1990), in a study with three $T$. pretiosum strains, observed that a population from Goiânia attacked twice more eggs of Anagasta kuehniella (Zeller) (Lepidoptera: Pyralidae) than a population from Iguatu. Bezerra \& Parra (2004), when evaluated the biology and parasitism of T. atopovirilia and T. pretiosum in eggs of Spodoptera frugiperda (J.E. Smith) (Lepidoptera, Noctuidae), also observed differences: T. atopovirilia show better acceptability and parasitism capacity over the host than T. pretiosum.

Viability also differed significantly $(\mathrm{p}<0.05)$ among Trichogramma species, ranging from $6.20 \%$, for $T$. acacioi, to $53.34 \%$, for T. atopovirilia (Table 1). Trichogramma viability is a factor closely related to the parasitoid-host affinity (Bezerra \& Parra, 2004). In Trichogramma production, quality control considers viability as satisfactory when the rate of borne adults exceeds $85 \%$ (Navarro, 1998). Thus, the species used in the present study expressed low affinity to the host. Gonçalves et al. (2003), when assessing the quality of $T$. pretiosum reared in Sitotroga cerealella (Oliver) (Lepidoptera: Gelechiidae) eggs, observed viability levels above $89 \%$, which denotes host quality and species affinity.

The sexual rate was similar in the three Trichogramma species, with values above 0.88 (Table 1). Considering that the quality control on Trichogramma production requires a sexual rate equal or above 0.5 (Navarro, 1998), the three species meet the criterion. These species are well-adapted to lab conditions, since they already produced several generations in such environment. Therefore, sexual rates are high (Pereira et al., 2004b), differing from the results reported by Navarro \& Marcano (1999) for T. atopovirilia and T. pretiosum fed in eggs of Helicoverpa zea (Bod.) (Lepidoptera: Noctuidae), respectively 0.56 and 0.49 .

Among the studied species, $T$. atopovirilia had the strongest affinity to the Diamondback moth for use in programs of biological control. $T$. atopovirilia showed the highest egg parasitism and viability, and a satisfactory sexual rate.

\section{REFERENCES}

BARROS R; VENDRAMIN JD. 1999. Efeito de cultivares de repolho, utilizadas para criação de Plutella xylostella (L.) (Lepidoptera: Plutellidae), no desenvolvimento de Trichogramma pretiosum Riley (Hymenoptera: Trichogrammatidae). Anais da Sociedade Entomológica do Brasil 28: 469476.

BEZERRA EB; PARRA JRP. 2004. Biologia e parasitismo de Trichogramma atopovirilia Oatman \& Platner e Trichogramma pretiosum Riley (Hymenoptera, Trichogrammatidae) em ovos de Spodoptera frugiperda (J.E. Smith) (Lepidoptera, Noctuidae). Revista Brasileira de Entomologia 48: 119-126.

BLEICHER E; PARRA JRP. 1990. Espécies de Trichogramma parasitóides de Alabama argillacea. II. Tabela de vida de fertilidade e parasitismo de três populações. Pesquisa Agropecuária Brasileira 25: 207-214.

GONÇALVES JR; HOLTZ AM; PRATISSOLI D; GUEDES RNC. 2003. Avaliação da qualidade de Trichogramma pretiosum (Hymenoptera:Trichogrammatidae) em ovos de Sitotroga cerealella (Lepidoptera: Gelechiidae). Acta Scientiarum Agronomy 25: 485-489. 
HAJI FNP; PREZOTTI L; CARNEIRO JS; ALENCAR JA. 2002. Trichogramma pretiosum para o controle de pragas no tomateiro industrial. In: PARRA JRP; BOTELHO PSM; CORRÊA-FERREIRA BS; BENTO JMS (eds). Controle biológico no Brasil: parasitóides e predadores. São Paulo: Manole, p. 477-494.

HASSAN AS. 1997. Seleção de espécies de Trichogramma para o uso em programas de controle biológico. In: PARRA JRP; ZUCCHI RA(eds). Trichogramma e o controle biológico aplicado. Piracicaba: FEALQ. p. 183-206.

HASSAN SA; HAFEZ MB; DEGRANDE PE; HIRAI K. 1998. The side-effects of pesticides on the egg parasitoid Trichogramma cacoeciae Marchal (Hym., Trichogrammatidae), acute dose-response and persistence tests. Journal of Applied Entomology 122: 569-573.

IMENES SDL; CAMPOS TB; RODRIGUES NETTO SM; BERGMANN EC. 2002. Avaliação da atratividade de feromônio sexual sintético da traça das crucíferas, Plutella Xylostella (L.) (Lepidoptera: Plutellidae), em cultivo orgânico de repolho. Arquivos do Instituto Biológico 69: 81-84.
NAVARRO MA. 1998. Trichogramma spp. Producción, uso y manejo en Colombia. Guadalajara de Buga: Impretec. 176 p.

NAVARRO R; MARCANO R. 1999. Preferencia de Trichogramma pretiosum Riley y $T$. atopovirilia Oatman y Platner por huevos de Helicoverpa zea (Boddie) de diferentes edades. Boletin de Entomologia Venezoelana 14: 8793.

PARRA JRP. 1997. Técnicas de criação de Anagasta kuehniella, hospedeiro alternativo para produção de Trichogramma. In: PARRA JRP; Zucchi RA (eds). Trichogramma e o controle aplicado. Piracicaba: FEALQ. p. 121150.

PARRA JRP; BOTELHO PSM; CORREAFERREIRA SB; BENTO JMS. 2002. Controle biológico: uma visão inter e multidisciplinar. In: PARRA JRP; BOTELHO PSM; CORRÊAFERREIRA BS; BENTO JMS (eds). Controle biológico no Brasil: parasitóides e predadores. São Paulo: Manole. p. 477-494.
PEREIRA FF; BARROS R; PRATISSOLI D; PARRA JRP. 2004a. Biologia e exigências térmicas de Trichogramma pretiosum Riley e T. exiguum Pinto \& Platner (Hymenoptera: Trichogrammatidae) criados em ovos de Plutella xylostella (L.) (Lepidoptera: Plutellidae). Neotropical Entomology 33: 231236.

PEREIRA FF; BARROS R; PRATISSOLI D. 2004b. Desempenho de Trichogramma pretiosum Riley e T. exiguum Pinto \& Platner (Hymenoptera: Trichogrammatidae) submetidos a diferentes densidades de ovos de Plutella xylostella (Lepidoptera: Plutellidae). Ciência Rural 34: 1669-1674.

VILLAS BÔAS GL; CASTELO BRANCO, M; MEDEIROS MA; MONNERAT RG; FRANÇA FH. 2004. Inseticidas para o controle da traça-das-crucíferas e impactos sobre a população natural de parasitóides. Horticultura Brasileira 22: 696-699. 